\author{
ks. Tadeusz Kasabuta \\ Uniwersytet w Biatymstoku
}

\title{
Prałatury i kanonie de gremio Kapituły Katedralnej Wileńskiej w okresie przedrozbiorowym
}

\section{PRELATURES AND CANONRIES DE GREMIO THE VILNIUS CATHEDRAL CHAPTER BEFORE THE PARTITIONS}

Formation of the Vilnius Cathedral Chapter was a long process since its inception in 1388 to the middle of the sixteenth century. As the capital city of the cathedral chapter of the Grand Duchy of Lithuania from the beginning of its existence in the system and the organization was inspired by the Cracow Cathedral Chapter. Under the papal foundation bull by pope Urban VI Pontifex Maximus to erect bishopric of Vilnius the first two of the Prelature were founded (provost and dean) and 10 canonries. All of them were endowed in 1387 by king Vladislav II Jagiello. The next four prelate names: custodian, archdeacon, scholastic and cantor, and two canonries were developed under the efforts of successive monarchs, bishops and Chapter. The structure of the Chapter was finally clarified around 1525, which since then consisted of six prelates and 12 canons. In such organizational frameworks the Vilnius corporation canons and prelates survived until the end of the Polish-Lithuanian Commonwealth. Individual members of the Chapter had a specific range of privileges and obligations which in the case of prelates were assigned to each of the dignity of the individual. Competence of canons were evolving, depending on the current needs. In the reporting period, the corporation prelates and canons in gremio constituted under the church law a control body of the actions of diocesan bishops, which was de facto institution co-managering of the diocese. 
Key words: Grand Duchy of Lithuania, Vilnius Cathedral, the cathedral chapter, the prelate, the canon, the chancellor.

\section{Wstęp}

Kapituły katedralne w drugim tysiącleciu chrześcijaństwa zachodniego odegrały pierwszorzędną rolę w strukturze organizacyjnej i ustroju diecezji, stając się, jako dobrze zorganizowane korporacje, ośrodkami nauki i kultury. Zaistniały jako centra kultu religijnego i ośrodki władzy kościelnej, z czasem stały się też szkołami prawa i administracji kościelnej, a nierzadko także państwowej. Zasadniczą rolę w powstaniu kapituł odegrały reformy cesarza Ludwika Pobożnego, skutkiem czego doszło do trwałego rozdziału pomiędzy vita canonica a vita monastica. Podstawowe znaczenie dla uformowania się kapituł katedralnych było przyznanie tym wspólnotom w ramach reformy gregoriańskiej prawa wyboru biskupa, co potwierdził konkordat wormacki z 1122 roku i odprawiony w rok później Sobór Laterański I. Na skutek tych przeobrażeń członkowie kapituł otrzymali stałe miejsca w chórze i głos na wspólnotowym posiedzeniu. Do grona tych wspólnot przyjmowano odtąd wyłącznie duchownych wyższych święceń (subdiakonów, diakonów, prezbiterów). Począwszy od XIII stulecia tylko członkom kapituł katedralnych i kolegiackich przysługiwał tytuł kanonika. Jeszcze przed końcem XII wieku uformowały się we wspólnotach kanoników godności, zwane personatami lub urzędami, a potem prałaturami oraz zwykłe kanonikaty in gremio.

\section{Formowanie się prałatur i kanonii de gremio w Kapitule Wileńskiej}

Kapituła Katedralna Wileńska ustanowiona na mocy upoważnienia papieża Urbana VI i za zgodą króla Władysława Jagiełły przez biskupa Dobrogosta mocą dekretu wykonawczego z drugiej połowy 1388 roku, jako Kapituła stołeczna Wielkiego Księstwa Litewskiego w swym ustroju i organizacji wzorowała się na analogicznej korporacji stołecznej w Koronie - Kapitule Katedralnej Krakowskiej i w swym pierwotnym składzie obejmowała dwie prałatury i dziesięć kanonii. Ustanowione wówczas dwie godności prałackie to prepozyt, określony w rzeczonym dokumencie jako ,pierwszy w godności duchowny po 
biskupie”, i dziekan z prawem ustanawiania duchownych pełniących posługę w katedrze, z wyjątkiem kanoników ${ }^{1}$.

Proces kształtowania się składu Kapituły wileńskiej trwał ponad 100 lat, a do jej rozwoju w zasadniczym stopniu przyczynili się kolejni panujący. W kilka lat po ustanowieniu pierwszych prałatów i kanoników ich skład został powiększony o prałata kustosza, o którym pierwsza wzmianka pochodzi już z $1397 \mathrm{roku}^{2}$. W roku 1435 kolejną prałature, archidiakonię, ufundował książę Zygmunt Kiejstutowicz ${ }^{3}$. Scholasteria i kantoria zostały utworzone przez biskupa Jana z Książąt Litewskich w $1522 \mathrm{roku}^{4}$. Biskup erygując te godności nie określił ich uposażenia, poprzestając jedynie na obietnicy, że takowe „sam opatrzy" ${ }^{2}$ Z tym się jednak nie śpieszył, jako że w rok później po otrzymaniu listów rekomendacyjnych na pierwszego prałata scholastyka, Kapituła zarzuciła biskupowi, że nic nie wie o funduszach na tę godność, ani nawet o jej erekcji, co sugeruje, że odnotowanemu rok wcześniej w aktach utworzeniu tych godności nie towarzyszył żaden dokument fundacyjny ani erekcyjny ${ }^{6}$. Biskup Jan zarzuty te skwitował krótkim nos erigimus, zaczem Kapituła przypomniawszy, że prałaci niekanonicy nie korzystają ani z refekcji, ani z dystrybucji, poprzestając jedynie na swych prestymoniach, oraz że na sesjach przysługuje im tylko głos w sprawach kościelnych, dotyczących wyłącznie diecezji, zgodziła się na instalację pierwszego prałata scholastyka. Na tych samych zasadach funkcjonowali też pierwsi prałaci kantorzy ${ }^{7}$. W tym też czasie, z pewnością po $1502 \mathrm{roku}$, przybyły jeszcze dwie kanonie ${ }^{8}$. Skład Kapituły

Kodeks dyplomatyczny katedry i diecezji wileńskiej, wyd. J. Fijałek, W. Semkowicz, t. 1, z. 1, Kraków 1948 (dalej: KDKDW), nr 13, s. 24-26.

KDKDW, nr 29, s. 50.

KDKDW, nr 139, s. 157.

Biblioteka Litewskiej Akademii Nauk (dalej: BLAN), fond 43, nr 141 (dalej: f.43-141), Suma privilegiorum fundationis super certis bonis Capitulo Vilnensi inscriptis, XVIII w., k. 6v.

BLAN, f.43-210, Acta Capituli Vilnensis (dalej: ACV), t. 1, t. 2 (1502-1546), k. 57.

Biblioteka Polskiej Akademii Nauk, sygn. 8903, Akta różne, k. 207-208, 211-220; J. Kurczewski, Kościót zamkowy od jego założenia aż do dni obecnych, cz. 3, Wilno 1916, s. 16.

BLAN, f.43-210, ACV, t. 1-2 (1502-1546), k. 65.

J. Fijałek, Kościót Rzymsko-katolicki na Litwie. Uchrześcijannienie Litwy przez Polskę i zachowanie $w$ niej języka ludu pod koniec Rzeczpospolitej, [w:] Polska i Litwa w dziejowym stosunku, Kraków 1914, s. 275-276. 
został ostatecznie ustalony przed 1525 rokiem, z tego bowiem czasu pochodzi wzmianka mówiąca już o 12 kanonikach ${ }^{9}$.

Biskup Jan z Książąt Litewskich aż do końca swych rządów w diecezji podejmował próby dalszego powiększenia liczby członków Kapituły, ale napotkał na stanowczy jej opór. W 1525 roku kreował pierwszego kanonika ad mensam episcopalem, co spotkało się z natychmiastowa reakcją Kapituły, która odmówiła mu udziału w jej dobrach stołowych. Biskup poprzestał zatem na przyznaniu swemu protegowanemu rocznego uposażenia z dóbr stołowych własnych i postanowił zaczekać na najbliższy wakans w stallach ${ }^{10}$. Kapituła nie zwlekając, w trzy dni później postanowiła, że kanonicy kreowani przez biskupa ad mensam episcopalem, nigdy nie będą korzystali z jakichkolwiek dochodów, praw i opcji przysługujących kanonikom Kapituły katedralnej, a poprzestaną tylko na tytule i biskupim funduszu. Przyznano im ostatnie miejsca w stallach i w kapitularzu, i to tylko na sesjach, podczas których omawiane będą sprawy dotyczące diecezji lub reformy duchowieństwa ${ }^{11}$. Jak wynika z akt protokołów sesji kapitulnych, kanoników ,stołu biskupiego" było zaledwie kilku. Ostatnia instalacja kanonika extra numerum 12 participantium miała miejsce w 1536 roku, czyli w ostatnim roku władania diecezją biskupa Jana ${ }^{12}$.

Formalnie do roku 1561 prałaci i kanonicy pod względem uposażenia stanowili dwie osobne kapituły. Prałaci utrzymywali się z należnych im, przywiązanych do każdej godności, dóbr prebendalnych, zaś kanonicy - z dóbr refekcyjnych, z których dochód dzielili między sobą oraz z dóbr prestymonialnych dawanych na uposażenie poszczególnych kanoników. Połączenie uposażeń obu kapituł miało miejsce w roku 1558 na mocy przywileju króla Zygmunta II Augusta, potwierdzonego 10 kwietnia 1561 roku w Krakowie przez legata papieskiego Bernarda Bonioannesa. Odtąd prałaci wspólnie z kanonikami zarządzali i korzystali z dóbr refekcyjnych Kapituły, a kanonicy zajmowali wakujące stalle po prałatach ${ }^{13}$

$9 \quad$ BLAN, f.43-210, ACV, t. 1-2 (1502-1546), k. 95.

$10 \quad$ Summaryjny wypis z protokołów Kapituty Katedralnej Wileńskiej (...) przez Xawerego Bohusza uczyniony, s. 53.

11 BLAN, f.43-210, ACV, t. 1-2 (1502-1546), k. 95.

12 Ibidem, k. 55.

13 Summaryjny wypis z protokołów Kapituty Katedralnej Wileńskiej (...) przez Xawerego Bohusza uczyniony, s. 57. 


\section{Precedencja}

Przywilejem prałatów było prawo precedencji, które pozwalało im zajmować w chórze, w kapitularzu i w procesjach miejsce przed kanonikami. Precedencja w gronie prałatów ukształtowała się w sposób naturalny, głównie w oparciu o kolejność chronologiczną powstawania poszczególnych godności. W przypadku zbieżności w czasie (prepozyt i dziekan oraz scholastyk i kantor) decydował stopień ważności pełnionych przez nich funkcji i wola kreatora rzeczonych godności. Tak więc ostatecznie, po ustanowieniu w 1522 roku godności scholastyka i kantora, kolejność prałatur, uświęcona niemal stupięćdziesięcioletnim zwyczajem, była następująca: prepozyt, dziekan, archidiakon, kustosz, scholastyk i kantor. Precedencja natomiast kanoników warunkowana była kapitulnym stażem zasiadającego tam duchownego. Im kanonik dłużej pozostawał w Kapitule, tym zajmował wyższą w niej pozycję ${ }^{14}$.

Tak uformowana precedencja w swym porządku nie budziła zastrzeżeń ani członków Kapituły, ani biskupa diecezjalnego, ani też osób postronnych. Pojawiające się na tym tle konflikty nie dotyczyły porządku i kolejności prałatur i kanonii, miały raczej charakter personalny związany z faktem zajmowania miejsc w stallach przez biskupów, zwłaszcza sufraganów. Stąd już 23 listopada 1587 roku Kapituła wydała dekret sankcjonowany przez biskupa Jerzego Radziwiłła, żeby

sufragan jako w godności biskupiej postanowiony miał pierwsze miejsce i stallę w kościele [katedralnym - T. K.] przed wszystkimi prałatami zaraz po wszystkich biskupach W.X.L, w kapitule zaś według prelatury lub kanonii swojej miejsce i głos swój mieć będzie ${ }^{15}$.

Ustalenia te nie zapobiegły sporom. Echa jednego z nich pozostały $\mathrm{w}$ protokołach sesji kapitulnych z roku 1685 , kiedy to sufragan białoruski, biskup Mikołaj Słupski, prałat archidiakon wileński, powołując się na starszeństwo w sakrze, zgłosił pretensję do najwyższego miejsca w Kapitule spośród zasiadających w niej biskupów. Kapituła stwierdziwszy, że „w Kościele godność wszystkich biskupów jednaka jest”, oraz że „dziekana od ufundowania katedry zawsze większa była godność od archidiakońskiej”, pierwsze miejsce przyznała dziekanowi, którym był wówczas sufragan żmudzki, biskup Benedykt Żuchorski. W tych okolicznościach do sprawy całej wmieszał się sufragan wileński, prałat kantor biskup Władysław Silnicki. Ten spostrzegłszy, że być może zaistnieje tu precedens, żeby nie być pominiętym, zgłosił

14 Relationes status Dioecesium in Magno Ducatu Lithuaniae, coll. P. Rabikauskas, vol.1. Dioeceses Vilnensis et Samogitiae, Romae 1971, s. 202. 
pretensję do pierwszeństwa przed wszystkimi biskupami. Ponieważ był to okres sede vacante po śmierci biskupa Mikołaja Stefana Paca, Kapituła zgodziła się z wnioskiem Silnickiego, który zaproponował, by decyzję w tej sprawie pozostawić przyszłemu biskupowi diecezjalne$\mathrm{mu}$, co natychmiast oprotestował Słupski ${ }^{16}$. Nowo ustanowiony biskup wileński, Aleksander Kotowicz, zaraz po ingresie do katedry w 1685 roku zaproponował Kapitule, by dotychczasowa precedencja została zachowana w chórze, kapitularzu i procesjach, natomiast podczas wystąpień okolicznościowych biskup sufragan wileński winien mieć miejsce pierwsze po biskupach diecezjalnych i innych senatorach, na co też Kapituła przystała ${ }^{17}$. Jak długo trwała ta praktyka - trudno powiedzieć, faktem jest, że więcej sporów na tym tle nie odnotowano.

\section{Zakres obowiązków}

Późniejsze zatwierdzenie przywileju króla Zygmunta II Augusta z 1558 roku, kompletu Kapituły Katedralnej Wileńskiej przez legata papieskiego Bernarda Bonioannesa określiło ogólnie obowiązki archidiakona i dziekana. Według tego dokumentu podstawowym i zasadniczym obowiązkiem prałata dziekana miała być troska o należyty porządek służby Bożej w katedrze. On miał dopilnować, by mansjonarze, kapelani, altarzyści i inni duchowni, zwłaszcza wikariusze kapitulni, klerycy seminarium duchownego i uczniowie szkoły przykatedralnej w przepisanym czasie i oznaczonym porządku wypełniali swe funkcje w świątyni katedralnej, a więc także we wszystkich jej kaplicach, w chórze, na procesjach i innych miejscach, w których Kapituła występowała oficjalnie jako korporacja. W jego kompetencji spoczywał, do czasu ustanowienia godności prałata kantora, śpiew i muzyka w katedrze. On tė̇ miał pełną władzę nad księżmi wikariuszami taką, jaką miał prałat dziekan kapituły krakowskiej ${ }^{18}$. Tak szeroki zakres obowiązków dziekana zmotywował Kapitułę do ustanowienia funduszu na jego pomocnika - poddziekana. Prałat dziekan został zobowiązany do ścisłej rezydencji przy katedrze. Nie miał prawa oddalić się od niej bez wyraźnej zgody biskupa i tylko za przyzwoleniem całej Kapituły. Zalecono też, by takowe pozwolenie otrzymywał rzadko, tylko w szczególnie ważnych sprawach, nigdy na dłużej, niż na trzy miesiące ${ }^{19}$. By

\footnotetext{
$16 \quad$ BLAN, f.43-226, ACV, t. 18 (1683-1685), s. 166.

17 BLAN, f.43-226, ACV, t. 18 (1683-1685), s. 179-180.

18 BLAN, f.43-221, ACV, t. 13 (1652-1663), k. 422.

19 Przywilej królewski z 1558 r. i dokument legata papieskiego z 1561 roku, wydał drukiem ks. J. Kurczewski [w:] Kościół zamkowy, cz. 2, Wilno 1910, s. 77-80.
} 
ułatwić dziekanowi sprawowanie funkcji, przydzielono mu kamienicę kanonicką położoną najbliżej katedry ${ }^{20}$.

Prałat archidiakon dany został właściwie do pomocy biskupowi ordynariuszowi. $Z$ jego mandatu, za wiedzą Kapituły lub w czasie sede vacante z jej polecenia, winien był wizytować parafie, dbać o ich uposażenie, troszczyć się o właściwe zarządzanie parafialnymi beneficjami ${ }^{21}$. Spod wizytacji archidiakona wyłączone były tylko beneficja parafialne, będące na uposażeniu Kapituły, które wizytowali delegowani przez Kościoła Kapitułę ad casum jej dwaj członkowie ${ }^{22}$. Prałat archidiakon przeprowadzał też egzaminy dla przystępujących do święceń kapłańskich. Do roku 1661 czynił to osobiście, później Kapituła wyznaczała mu do asysty dwóch biegłych $\mathrm{w}$ teologii lub prawie kanoników ${ }^{23}$. Ponieważ przywilej królewski z 1558 roku zawierał jedynie ogólne wytyczne, co do funkcji prałata archidiakona, wkrótce pojawiły w łonie Kapituły różnice co do szczegółowej interpretacji tegoż dokumentu. Archidiakon Andrzej Patrycy, wyjeżdżając w 1588 roku z biskupem Jerzym Radziwiłłem na wizytację, wniósł prośbę, by za czas jego nieobecności wypłacono należną mu, jego zdaniem, refekcję. Kapituła odmówiła, stwierdziwszy, że w podróż tę wybiera się nie jako wizytator, lecz ,jako domowy biskupa i rewizor dóbr jego, chociażby po drodze i kilka kościołów zwizytował" "24. Sprawa stanęła na najbliższej sesji generalnej jesiennej 13 października 1588 roku i została rozwiązana mocą wydanej na podstawie ustaleń Tridentinum i przywileju z 1558 roku uchwały w formie dekretu. Stanowił on, że prałat archidiakon, wizytujący za wiedzą Kapituły parafie, będzie otrzymywał prezencję w Kapitule i wszystkie związane z tym należności co trzeci rok i to pod warunkiem, że wizytowanie parafii będzie wyłącznym celem jego wyjazdu ${ }^{25}$. Dekret ten przypomniano i potwierdzono raz jeszcze w roku $1609^{26}$.

Prałat kustosz już w XIV wieku przejął część obowiązków dziekana. Odpowiedzialny był z urzędu za skarbiec katedralny w najszerszym tego pojęcia znaczeniu ${ }^{27}$. Dbał nie tylko o kosztowności przechowywane

\footnotetext{
$20 \quad$ BLAN, f.43-217, ACV, t. 9 (1625-1632), k. 150.

21 J. Kurczewski, Kościót zamkowy, cz. 2, op. cit., s. 78.

22 BLAN, f.43-216, ACV, t. 8 (1602-1624), s. 216-317.

$23 \quad$ BLAN, f.43-221, ACV, t. 13 (1652-1663), k. 273.

24 BLAN, f.43-215, ACV, t. 7 (1586-1601), s. 100.

25 Ibidem, s. 108

26 BLAN, f.43-216, ACV, t. 8 (1602-1624), s. 149.

27 B. R. Vitauskienè, Pasvarstymai apie seniausias katedros vertybes, „Naujasis Židinys - Aidai”, 2003, nr 10, s. 542-548.
} 
w katedrze. W jego gestii było utrzymanie w należytym porządku całego jej wyposażenia. On czuwał też nad funduszem przeznaczonym na zaopatrzenie świątyni we wszystkie utensylia liturgiczne, stanowiące uposażenie zarówno ołtarza kanonickiego, jak też kaplic, mansjonarii i altarii. Miał w swej pieczy zakrystię kanonicką i wikariuszowską. Jemu zgłaszano wszelkie bieżące potrzeby dotyczące utensyliów liturgicznych, wosku, hostii, wina mszalnego, kadzidła ${ }^{28} . \mathrm{Z}$ drugiej połowy XVIII stulecia pochodzi wzmianka świadcząca, że już w ubiegłym stuleciu trzymał on pieczę nad dwiema kasami: funduszem na obie zakrystie i na tzw. sartatecta, czyli na środki przeznaczone na naprawę i ewentualną rozbudowę świątyni katedralnej.

Finansami zarządzał i dbał o ich bezpieczeństwo katedralny podskarbi. W roku 1765 Kapituła mając świadomość wysokości dysponowanych sum i niemożności dokładnej ich kontroli, pragnąc zabezpieczyć się przed defraudacją poprzez gospodarowanie tymi środkami bez jej wiedzy, wprowadziła ścisłą kontrolę nad ich dystrybucją. W tym celu, na wniosek kustosza, nakazała precyzyjnie rozdzielić fundusz na zakrystię i na sartatecta i obie sumy złożyć osobno u podskarbiego. O każdej inwestycji kustosz winien odtąd powiadamiać Kapitułę, która, jako korporacja, asygnowała na poszczególne cele potrzebne środki. Podskarbi winien był notować wszystkie wydatki w osobnej księdze, a od wydających pieniądze żądać stosownego pokwitowania ${ }^{29}$. Osobną funkcją prałata kustosza, poprzez którą wchodził po części w kompetencje dziekana, było ustalanie godzin odprawiania Mszy św. w kaplicach i przy ołtarzach bocznych ${ }^{30}$. W pełnieniu obowiązków prałata kustosza wspierał, zajmując się bezpośrednio realizacją jego poleceń, podkustoszy.

Prałat scholastyk, po utworzeniu tej godności, przejął część dotychczasowych obowiązków dziekana i kustosza. W jego gestii leżała troska o szkołę bądź szkoły przykatedralne ${ }^{31}$. Prałat scholastyk początkowo zapewne uczył osobiście, potem, trudno dokładnie ustalić kiedy, otrzymał prawo prezentowania nauczycieli. Tych, po stwierdzeniu

28 KDKDW, nr 29, s. 50; G. Zujienè, Historia skarbca katedry wileńskiej (od założenia do dzisiaj, [w:] Skarbiec katedry wileńskiej, Warszawa 2008, s. 31-32.

BLAN, f.43-236, ACV, t. 28 (1753-1766), s. 12.

BLAN, f.43-227, ACV, t. 19 (1685-1698), s. 615-616.

W. Plöchl, Geschichte des Kirchenrechts, Bd 1, Wien 1959, s. 351, Bd 2, Wien 1962 , s. 157 nn., 494; W. Abraham, Organizacja Kościoła w Polsce do połowy wieku XII, Lwów 1890, s. 182; J. Kurczewski, Kościót zamkowy, cz. 2, op. cit., s. 45-47. 
ich przydatności, mianowała Kapituła ${ }^{32}$. Sobór Trydencki 15 lipca 1563 roku na sesji XXIII uroczyście zobowiązał biskupów diecezjalnych do zakładania szkół świeckich dla uboższej młodzieży oraz by ci mając w swych kapitułach prałatów scholastyków, przypomnieli im dotychczasowe obowiązki, przede wszystkim ten, odnoszący się do rzetelnej selekcji nauczycieli i eliminowania tych kandydatów, którzy do tej funkcji nie mają predyspozycji czy to intelektualnych, czy też moralno-obyczajowych. Scholasterie, według ojców soborowych

nadawane mają być tylko doktorom, magistrom, bądź licencjatom teologii lub prawa kanonicznego, osobom urząd ten pełnić zdolnym. Inaczej zamianowanie ich na ten urząd traci jakiekolwiek znaczenie bez względu na przywileje, bądź jakiekolwiek, choćby i najdawniejsze zwyczaje ${ }^{33}$.

Zgodnie z tymi uchwałami w końcu XVI i na początku XVII stulecia szkolnictwo przykatedralne w Wilnie poczęło rozwijać się bardziej dynamicznie, zwłaszcza od czasu, gdy w 1579 roku biskup Walerian Protasewicz założył pierwszą w Wilnie bursę dla uboższych uczniów, nazwaną od jego imienia „waleriańską" "34. Z kolei w 1602 roku kanonik Ambroży Beynart ufundował szkołę dla ubogiej młodzieży, zwaną „bursą ambrozjańską” lub „beynartowską, zaś Jan Mikołaj Korsak w roku 1610 - kolejną bursę, określaną z czasem mianem „korsakowskiej" ${ }^{35}$. Z natury rzeczy zatem, na mocy rzeczonych uchwał Tridentinum, prałat scholastyk wileński nie mógł być tym instytucjom obcy. Jego zadaniem była troska o zatrudnienie odpowiednich nauczycieli, piecza nad postępami uczniów w nauce, kontrola tych szkół i dbałość o należyte warunki materialne. Słusznym wydaje się przypuszczenie, że kompetencje scholastyka w Kapitule Wileńskiej odpowiadały tym, które określił były biskup wileński, a następnie krakowski, kardynał Jerzy Radziwiłł w dekrecie reformacyjnym dotyczącym prałata scholastyka Kapituły krakowskiej z 1596 r. Zapisano tam, że

scholastyk (...) jest odpowiedzialny za szkołę katedralną, nauczanie i wychowanie młodzieży, a więc jej kształcenie w nauce chrześcijańskiej i artes liberales. Winien mieć doktorat lub odpowiednią wiedzę. On

$32 \quad$ BLAN, f.43-214, ACV, t. 6 (1578-1585), s. 41-45.

33 Dokumenty soborów powszechnych. Tekst taciński i polski, t. 4 (1511-1870): Lateran V, Trydent, Watykan I, oprac. A. Baron, H. Pietras, Kraków 2005. 
instytuuje magistra - kierownika szkoły, a także zwalnia go z urzędu za uprzednią zgodą Kapituły ${ }^{36}$.

O ścisłym związku scholastyka ze szkolnictwem przykatedralnym świadczy przypomniany przez Kapitułę w 1676 roku zwyczaj, by fundusz wakującej scholasterii przeznaczać na budowę szkółki przykatedralnej ${ }^{37}$.

O działalności prałata kantora w zakresie utrzymania porządku w śpiewie kościelnym i muzyce w katedrze, niewiele w świetle akt archiwalnych Kapituły Wileńskiej, można powiedzieć. Wiadomo, że przejął on część obowiązków dziekana i kustosza ${ }^{38}$. Kapituła w Wilnie, co wyjątkowo często podkreślają autorzy źródeł rozmaitej proweniencji i rangi - w swym ustroju i organizacji wzorowała się na Kapitule Katedralnej Krakowskiej, stąd powszechną praktyką w diecezji wileńskiej było odnoszenie się do Krakowa, jako wzorca. W wielu wypadkach nie widziano potrzeby, by określać w szczegółach kompetencje i obowiązki członków Kapituły wileńskiej i poprzestawano na stwierdzeniu „tak, jak w Kapitule krakowskiej”. Tam zaś zasadniczym obowiązkiem prałata kantora było czuwanie nad zespołami i kolegiami śpiewaczymi w chórze i podczas procesji. Kardynał Jerzy Radziwiłł, który po biskupstwie wileńskim objął w 1591 roku stolicę diecezji krakowskiej, w roku 1596 stwierdził, że

kantor przewodzi śpiewem katedralnym, aby odpowiadał randze świąt i był łagodny, nie gwałtowny. On też winien rozpoczynać antyfony w czasie nieszporów i jutrzni, rozdzielać lekturę dziennych i nocnych Officium divinum. Osobiście ma przewodniczyć śpiewom w czasie celebry biskupiej. Do jego obowiązków należy również karanie tych plebanów miasta, którzy nie biorą udziału w dorocznych procesjach katedralnych ${ }^{39}$.

Kantor w Kapitule Wileńskiej odpowiedzialny był za muzykę w katedrze i to nie tylko muzykę organową. Kiedy w końcu XVII wieku podczas uroczystych celebr pojawiły się $\mathrm{w}$ katedrze inne instrumenty muzyczne, zaistniała potrzeba odpowiedniego doboru muzyków i ich

$36 \quad$ Statuta Capituli Ecclesiae Cathedralis Cracoviensis A. 1328-1478, [w:] H. Heyzman (red.), Staropolskie Prawa Pol. Pom., t. 4, Cracoviae 1875, s. 246.

BLAN, f.43-216, ACV, t. 8 (1602-1624), s. 66; BLAN, f.43-216, ACV, t. 17 (16731682), s. 228.

BLAN, f.43-210, ACV, t. 1-2 (1502-1546), k. 57.

39 I. Polkowski (red.), Statuta capitularia Ecclesiae Catherdralis Cracoviensis, Cracoviae 1884, s.246 nn.; B.Przybyszewski, Kapitutakrakowskazakanonikatu Jana Dtugosza (1438-1480), [w:] Dtugosiana. Studia historyczne w pięćsetlecie śmierci Jana Dtugosza, Kraków 1980, s. 40-41. 
permanentne kształcenie. Zwrócił na to uwagę biskup Konstanty Kazimierz Brzostowski w 1705 roku, gdy polecił Kapitule, by ta, na miarę posiadanych środków, powiększyła kapelę katedralną poprzez zwiększenie liczby muzyków i instrumentów. Kapituła bez sprzeciwu zleciła wypełnienie tego postulatu prałatowi kantorowi ${ }^{40}$. Dysponował on po temu odpowiednimi środkami, jako że sprawował nadzór nad powstałą w początkach XVIII stulecia tzw. bursą śpiewaczą. Była to szkoła na kształt konserwatorium muzycznego, w której uczono zaHistoria równo śpiewu gregoriańskiego, jak i figuralnego (polifonicznego), ale nie tylko. Umiejętności swe doskonalili tu także organiści i muzycy grający na „różnych instrumentach" ${ }^{41}$. W pełnieniu obowiązków swego urzędu prałata kantora wspierał, a z czasem coraz częściej wprost zastępował, podkantor.

Osobliwą pozycję w Kapitule Wileńskiej zajmował prałat prepozyt. Poza stwierdzeniem w dokumencie wykonawczym biskupa Dobrogosta, że jest on „pierwszy w godności po biskupie”, żadne akta normatywne, ani inne nie rozpisują się specjalnie na temat jego kompetencji. Trudno w tym kontekście oprzeć się wrażeniu, że Kapituła wileńska u początku swej organizacji znalazła się w niejakim kłopocie. Posiadając początkowo w swym składzie prepozyta i dziekana, w takiej właśnie kolejności, otrzymała jednocześnie wskazówki, by w swym ustroju i organizacji czerpać wzory z Kapituły Katedralnej Krakowskiej, której przewodził nie prepozyt, a dziekan. Prepozytura była tam drugą w hierarchii (po dziekanii) godnością, zaś w chórze prepozyt zasiadal na trzecim miejscu, po dziekanie i archidiakonie ${ }^{42}$. Powszechnym zjawiskiem w kapitułach polskich, w których na czele stał dziekan, było, że obowiązki prepozyta obejmowały zakres zdecydowanie skromniejszy, niż tam, gdzie ten kapitule przewodniczył. W Wilnie zatem prepozytura na mocy dokumentu erekcyjnego była pierwszą godnością, jednakże na wzór Krakowa, obowiązki prepozyta były skromne i nie do końca określone, bo niemal wszystkie jego kompetencje, na wzór Krakowa, posiadał dziekan. Obowiązki prepozyta katedralnego wileńskiego w praktyce sprowadzały się do tego, że był on „pierwszy” i znany był z tego, że był „znany” ${ }^{3}$.

40 BLAN, f.43-228, t. 20 (1698-1709), k. 123-123v.

$41 \quad$ BLAN, f.43-232, t. 24 (1727-1731), k. 102.

42 Statuta capitularia Ecclesiae Catherdralis Cracoviensis, s. 245.

$43 \quad$ Znamienne dla Kapituły Katedralnej Wileńskiej jest, że pierwszy w godności prałat prepozyt w drugiej połowie XVII i w wieku XVIII często bywał nieobecny na sesjach, jeszcze rzadziej pojawiał się w chórze i na procesjach, mimo że przez to tracił refekcje. Dowodzą tego protokoły sesji generalnych i partykularnych 


\section{Kanonik-kanclerz}

Osobną i dość skomplikowaną w przypadku Kapituły Katedralnej Wileńskiej jest obecność w jej składzie kanonika-kanclerza ${ }^{44}$. Kapituły koronne, w których gronie kanclerze zaistnieli najwcześniej: gnieźnieńska - $1139^{45}$, wrocławska $-1200^{46}$, krakowska - $1295^{47}$, poznańska - $1298^{48}$, płocka - $1322^{49}$, nie przewidywały początkowo dla owych urzędników osobnych stalli, ani beneficjów ${ }^{50}$. Nie inaczej było w Kapitule Wileńskiej, gdzie obowiązki kanclerza pełnił jeden z aktualnych

oraz wykazy rozdysponowanych sum refekcyjnych, w których skrupulatnie odnotowywano prezencję. Jeszcze bardziej zastanawiający jest fakt, że z tego tytułu nie był upominany ani w inny sposób monitowany. Widać jego obecność niewiele wnosiła, a absencja nie przeszkadzała. BLAN,f.43-673, Percepta masae (...) Cap. Vilnensis pro consolationibus et omnibus obventionibus, 1685-1686, $\mathrm{k}$. 4; BLAN, f.43-1128, Rozdziat refekcyjnej summy, 1791-1792, k. 1.

Dotychczasowe wyniki badań dotyczące ustroju i organizacji kapituł w Polsce i w Wielkim Księstwie Litewskim pozostawiają otwartą kwestię i nie upoważniają do jednoznacznej odpowiedzi na pytanie, czy godność kanclerza w kapitułach katedralnych i kolegiackich zaistniała ze względów wyłącznie praktycznych, jako odpowiedź na pojawiające się nowe zadania, czy też u podstaw kanclerstwa kapitulnego legły motywy natury ambicjonalnej: kanclerza posiadał król, posiadał prymas, biskup diecezjalny, dlaczego nie kapituła. H. E. Wyczawski, Przygotowanie do studiów w archiwach kościelnych, Kalwaria Zebrzydowska 1990, s. 178.

W. Abraham, Organizacja Kościoła w Polsce, op. cit., s. 182.

K. Dola, Wrocławska kapituła katedralna w XV wieku. Ustrój-skład osobowy - działalność, Lublin 1983, s. 29.

B. Kumor, Dzieje diecezji krakowskiej do roku 1794, t. 2, Kraków 1999, s. 288-289.

J. Nowacki, Dzieje archidiecezji poznańskiej, t. 2, Archidiecezja poznańska w granicach historycznych i jej ustrój, Poznań 1964, s. 290.

W. Góralski, Kapituła katedralna w Płocku XII-XVI w. Studium z dziejów organizacji prawnej kapitut polskich, Płock 1979, s. 84.

W początkach funkcjonowania godności kanclerskiej w kapitułach koronnych kanclerz pełnił funkcje reprezentacyjne. Miał on przydać kapitule splendoru i świadczyć o jej majestacie. Nic zatem dziwnego, że kapituły tak wielką wagę przywiązywały do obecności kanclerzy podczas uroczystości, w czasie których w sposób czynny zaznaczały swą obecność, im właśnie powierzając najczęściej zadanie wygłoszenia okolicznościowego przemówienia i zazwyczaj tylko tyle. $\mathrm{Z}$ czasem zaczęto wynajdywać kanclerzowi rozmaite zajęcia, m.in. powierzono mu opiekę nad pieczęcią kapitulną z prawem pieczętowania w imieniu kapituły jej akt i dokumentów, jemu też najczęściej oddawano w opiekę kapitulne archiwum. J. Bartoszewicz, Kanclerze kapitut, [w:] Encyklopedia Powszechna S. Orgelbranda, t. 13, Warszawa 1863, s. 904. 
członków Kapituły, zazwyczaj biegły w prawie kanonik, zwany prokuratorem spraw ${ }^{51}$.

W przypadku większości kapituł przedrozbiorowych trudno jest dokładnie określić datę ustanowienia osobnej godności kanclerskiej z własnym uposażeniem i stallą. Ponieważ godność ta pojawiła się dość późno w stosunku do innych, stąd kanclerz zazwyczaj zajmował w kapitule miejsce ostatnie wśród prałatów, ale przed kanonikami. Tak było w kapitułach katedralnych w Gnieźnie, Krakowie, Włocławku, Poznaniu, Przemyślu, Chełmie i Kamieńcu Podolskim. W przypadku kilku kapituł kanclerstwo stało wyżej od niektórych godności prałackich, tych mianowicie, które powstały w porządku chronologicznym później, niż godność prałata-kanclerza. W kapitule lwowskiej kanclerz poprzedzał kantora, w płockiej - prałatów archidiakonów dobrzyńskiego i pułtuskiego, w łuckiej - kantora i scholastyka, w kijowskiej - archidiakona czernihowskiego, w inflanckiej - kantora ${ }^{52}$.

Na tym tle jako zupełnie wyjątkowa jawi się pozycja kanclerza w Kapitule Katedralnej Wileńskiej, gdzie ten nigdy nie dorósł do godności prałackiej, zadowalając się niepewną pozycją ostatniego kanonika. Zagadnienie to jest o tyle absorbujące, że przypadek Wilna stanowi pierwszy w Rzeczypospolitej, dość dobrze udokumentowany wzór ustanowienia osobnego kanclerstwa, od początku niezwiązanego z żadną godnością kapitulną.

Początki kanclerstwa wileńskiego sięgają roku 1626, kiedy to ziemianin z powiatu oszmiańskiego, Aleksander Korecki, 2 października „chcąc pamiątkę imienia swego potomności zostawić” legował na Jaszunach, dobrach księcia Krzysztofa Radziwiłła, hetmana polnego Wielkiego Księstwa Litewskiego, odpowiednią sumę i nadał dobra Cudzieniszki, jako fundusz przyszłego kanclerza kapitulnego i diecezjalnego jednocześnie ,in gremio capituli być mającego" ${ }^{53}$. Prawo patronatu na tę kanonię fundator przekazał biskupowi wileńskiemu i Kapitule ${ }^{54}$.

Kapituła donację przyjęła bez żadnych zastrzeżeń. Te pojawiły się dopiero wtedy, gdy biskup Eustachy Wołłowicz począł w czerwcu 1629 roku domagać się pełnej egzekucji woli fundatora. Wówczas to ujawniły się po raz pierwszy w omawianej materii, póki co ostrożne jeszcze, ale wyraźne różnice zdań pomiędzy Kapitułą, a biskupem. $\mathrm{Na}$ indagacje rządcy diecezji, by ustanowić kanclerza i wprowadzić

\footnotetext{
51 Ibidem, s. 904.

52 Ibidem, s. 909.

53 BLAN, f.53-708, Wiadomość o stanie kanclerstwa wileńskiego, b.d., k.nlb. 
go do Kapituły, część jej członków zgłosiła natychmiast zastrzeżenia, twierdząc, że byłoby to „przeciw prawu i zwyczajom”55. Zirytowany tym biskup, nie czekając, w kilka dni później podjął sprawę na nowo i już w zdecydowanej formie niemalże zażądał wprowadzenia kanclerza do kapitulnego gremium ${ }^{56}$. Kapituła, jak się wydaje, znalazła się w sytuacji dość niezręcznej, jako że część jej członków ewentualną decyzję o przyznaniu kanclerzowi miejsca w stallach oprotestowała, co z kolei uniemożliwiło jej podjęcie w trybie natychmiastowym, na sesji partykularnej, jakichkolwiek w tej sprawie decyzji ${ }^{57}$. Stąd odpowiedź prałatów i kanoników z dnia 6 września 1629 roku o odłożeniu sprawy do najbliższej sesji generalnej. Jakoż i dnia 9 października tego roku biskup doczekał się decyzji Kapituły. Ta po dłuższej deliberacji uznała, że kanclerz w Kapitule nie jest ani potrzebny, ani tym bardziej konieczny, co sugerował rządca diecezji. Przeciwnie, ustanowienie urzędu i godności kanclerskiej w Kapitule może okazać się szkodliwe. Wśród przytoczonych argumentów zebrani na sesji członkowie Kapituły zauważyli, że o kanclerzu nie ma wzmianki w uchwałach Tridentinum, nie ma mowy w prawie kościelnym powszechnym, ani też w partykularnym. Powołano się na przykład Kapituły Krakowskiej, która w momencie erekcji nie posiadała godności kanclerskiej,jak też nie posiada chwilowo i teraz, a mimo to funkcjonowała i funkcjonuje sprawnie, załatwiajac swoje interesy przez przewidzianych statutem prokuratorów spraw. Poza tym - zdaniem Kapituły -

dictus Cancelarius iuxta propositionem et mentem ipsiusmet Ilmi et Rmi Dni duplicis subsellit foret: curiae videlicet episcopalis et capitularis, ob quam suam bipartitam divisionem et neutralitatem, neutri etiam subsellio sufficienter serviet, iuxta illud evangelicum: nemo potest duobus Dominis servire ${ }^{58}$.

Podkreślono też wyraźnie, iż byłoby to pewne novum pozostające, zdaniem Kapituły, w sprzeczności z jej statutami, jako że tak wprowadzony kanclerz zniósłby urząd przewidzianych statutem prokuratorów kapitulnych. Ustanowiony w ten sposób kanclerz, w sytuacji, gdyby ze względu na stan zdrowia, podeszły wiek lub z innych względów nie mógł pełnić obowiązków swego urzędu, musiałby być zastąpiony przez innego duchownego, któremu należałoby przydzielić godziwe uposażenie, „które nie wiadomo skąd brać by trzeba było”. Kapituła

$55 \quad$ Ibidem, k. 109.

$56 \quad$ Ibidem, k. 126.

57 BLAN, f.43-708, Wiadomość, k.nlb. 
przewidziała też możliwość zaistnienia w związku z urzędem kanclerza ewentualnego konfliktu pomiędzy nią a biskupem. W sytuacji bowiem, gdyby kanclerz nie sprostał oczekiwaniom rządcy diecezji, ten mógłby go zdymisjonować i ustanowić innego, który otrzymałby całość kanclerskiego beneficjum, pozostawiając dotychczasowego kanclerza bez środków do życia. Ponadto samo uposażenie kanclerza było niepewne, bo lokowane na dobrach obciążonych długami ${ }^{59}$.

Pomijając sprawę zasadności powyżej przytoczonych argumentów, Kościoła warto zwrócić uwagę na pewien historyczny paradoks. Otóż, podczas gdy u podstaw ustanowienia w kapitułach koronnych godności kanclerskiej leżało pragnienie przydania sobie splendoru i dorównania urzędom świeckim, o tyle Kapituła Wileńska nie widziała takiej potrzeby i w swej decyzji o ewentualnej erekcji kanclerstwa kierowała się racjami czysto praktycznymi i względami ekonomicznymi. To biskupowi, nie Kapitule, zależało na wprowadzeniu kanclerza do stalli, a to w tym zdaje się celu, by poprzez jego osobę mieć większy wpływ na decyzje Kapituły. Ta zaś świadoma tych zagrożeń, wolała raczej zrezygnować z dodatkowego, wątpliwego zresztą, splendoru, niż ryzykować osłabienie swych w stosunku do biskupa prerogatyw, pozycji, dla której kanclerz mógł w przyszłości stanowić zagrożenie.

W ten sposób umotywowawszy swe stanowisko i wyłuszczając pomniejsze jeszcze racje, Kapituła nie zwlekając oznajmiła biskupowi swój werdykt, twierdząc, że nie widzi potrzeby, ani możliwości wprowadzenia do swego grona nowego członka - kanclerza ${ }^{60}$. Biskup Wołłowicz zapewne jedynie kurtuazyjnie czekał na tę odpowiedź, jako że nie bacząc na jej brzmienie, w ciągu trzech tygodni, sobie tylko wiadomym sposobem, zmontował w Kapitule mniejszościową koalicję złożoną z młodszych kanoników i przy ich pomocy osadził w stalli kapitulnej ustanowionego przez siebie kanclerza, proboszcza kowieńskiego, księdza Bartłomieja Cieszyńskiego, wyznaczając mu miejsce po ostatnim kanoniku ${ }^{61}$. Nietrudno było przewidzieć reakcję pozostałych członków Kapituły. Bezpośrednio po tak dokonanej instalacji ksiądz Jan Karol Bałłozor, prepozyt, dnia 2 listopada 1629 roku uroczyście w imieniu pozostałej części kapitulnego kolegium, oprotestował instalację Cieszyńskiego i napiętnował postawę tych kanoników, którzy stanęli w tej sprawie po stronie biskupa za to, że ci ważyli się wbrew prawu, bez wiedzy i zezwolenia starszych członków Kapituły na podobne bezprawie. Prepozyt nie omieszkał tu przypomnieć procedurę wprowadzenia

\footnotetext{
59 Ibidem, k. 132v.-133; J. Kurczewski, Biskupstwo wileńskie, op. cit., s. 381-382.

60 BLAN, f.F43-217, ACV, t. 9 (1625-1632), k. 132v.-133.

61 BLAN, f.43-708, Wiadomość, k.nlb.
} 
i instalacji nowego członka Kapituły po to, by stwierdzić, że niemal żaden z wymaganych warunków nie został tu spełniony ${ }^{62}$.

Protest ów na niewiele by się zdał, gdyby w niespełna miesiąc później do wieczności nie przeniósł się był główny orędownik stalli dla kanclerza, biskup Eustachy Wołłowicz. W ten sposób po jego śmierci sprawa pozostawała nadal otwarta, mało tego, znalazła swój odzew na szerszym forum, bo zainteresował się nią dwór królewski i nuncjatura w Warszawie. Dnia 16 stycznia 1630 roku król Zygmunt III Waza i nuncjusz apostolski w Warszawie, arcybiskup Antonio Santacroce, korespondencyjnie poczęli indagować Kapitułę w sprawie kanclerstwa ${ }^{63}$. Tym razem Kapituła, nadal niechętna oglądać kanclerza w swoim gronie, nie siliła się na wymyślną argumentację, stwierdzając krótko i rzeczowo, że w czasie sede vacante decyzji tak ważkich podejmować nie jest władna ${ }^{64}$. Niemniej naciski owe odniosły jakiś skutek, skoro 30 września 1631 roku kanclerz Cieszyński uczestniczył w sesji Kapituły i został utytułowany jako kanonik ${ }^{65}$.

Następca biskupa Wołłowicza, biskup Abraham Woyna już na początku rządów diecezją dał do zrozumienia, że w sprawie kanclerstwa podtrzyma linię swego poprzednika i już 12 marca 1632 roku wśród trzech postulatów przekazanych Kapitule, na pierwszym miejscu postawił żądanie, by szacowne kolegium zechciało wybrać i prezentować mu kandydata na kanclerza. Kapituła w swym stanowisku pozostała także konsekwentna, skutkiem czego biskup usłyszał w odpowiedzi, że przy całym szacunku dla swego pasterza, podtrzymuje ona swe stanowisko i dla ,poważnych przyczyn” kanclerza w swym gronie nie akceptuje. Na tej samej sesji podjęto uchwałę, na mocy której Kapituła zrzekła się „po wieczne czasy” prawa do funduszu kanclerstwa, wszelkie prerogatywy w tym względzie przekazując biskupowi. Biskup zatem, obecny na sesji 19 marca 1632 roku, by sprawę ostatecznie zamknąć, oświadczył, że na mocy praw kolatorskich przekazuje na uposażenie kanclerza dobra Cudzieniszki i sumę w wysokości 300 złp. lokowaną na Jaszunach. Odtąd przez lat kilkanaście jeden z członków Kapituły pełnił jednocześnie obowiązki kanclerza biskupiego. Już w roku 1633 na sesji Kapituły był obecny kanclerz biskupi, kanonik Mateusz Pogrecki. Tenże duchowny w trzy lata później doczekał się awansu i 6 stycznia 1636 roku objął stalle prałata kantora. Urząd kanclerza pełnił do śmierci, która dosięgła go w zimie 1645 roku. Jego

\footnotetext{
$62 \quad$ BLAN, f.43-217, ACV, t. 9 (1625-1632), k. 134-134v.

63 BLAN, f.43-708, Wiadomość, k.nlb.

64 BLAN, f.43-217, ACV, t. 9 (1625-1632), k. 170-170v.

65 BLAN, f.43-708, Wiadomość, k.nlb.
} 
miejsce zajął i do Kapituły instalowany został dnia 8 kwietnia 1645 roku ksiądz Wawrzyniec Mocarski ${ }^{66}$.

Miejsce kanclerza w Kapitule nie było jednak ciągle do końca zdefiniowane, nawet Kapituła - zdaje się - miała problemy z określeniem pozycji i prerogatyw kanonika-kanclerza. Widać to wyraźnie w odpowiedzi na postulat biskupa Jerzego Tyszkiewicza z 16 maja 1650 roku, domagającego się dla kanclerza miejsca w kapitularzu i prawa czynnego głosu na sesjach kapitulnych. Odmowna odpowiedź KapiHistoria tuły, motywującej swe stanowisko argumentem, iż kanclerz „zgoła nie należy do Kapituły" dowodzi, iż instalowani w Kapitule duchowni z tytułu pełnienia urzędu kanclerskiego nie nabywali w pełni praw stałego jej członka ${ }^{67}$. Konsekwentnie odmawiano im prawa udziału w sesjach kapitulnych, dopuszczeni zaś do kapitularza, nigdy nie posiadali prawa czynnego głosu, przez co nie mieli żadnego wpływu na decyzje Kapituły, na czym tak bardzo zależało biskupom wileńskim ${ }^{68}$.

W drugiej połowie XVII stulecia relacje na linii kanclerz - Kapituła z pozycji nieufności powoli zaczynały ewoluować w kierunku odejścia od wzajemnych uprzedzeń, poprzez ostrożną współpracę, aż po układ niemal partnerski. Kanclerz diecezjalny zaczął być Kapitule coraz bardziej potrzebny. Znać to zwłaszcza po najściu moskiewskim (1656-1662) i dokonanych przez Moskali spustoszeniach dóbr kościelnych. Zasoby archiwum kapitulnego, dość mocno przetrzebione, ale w zasadniczej swej masie uratowane, potrzebowały uporządkowania, jako że w rozlicznych teraz sprawach sądowych prowadzonych przez duchownych, zaczęto coraz częściej po nie sięgać. Wówczas urząd i osobę kanclerza, jako odpowiedzialnego za zbiory dokumentów fundacyjnych i całego zasobu archiwalnego, zaczęto cenić i motywować do pracy. Wyraźnie widać to już w 1666 roku, gdy Kapituła dnia 12 maja zwróciła się z prośbą do kanonika Beynarta, by ten nie sprzeciwiał się przyjęciu kanclerstwa, oraz aby po objęciu tego urzędu, pomimo groźby kolejnego najazdu moskiewskiego, pozostał w Wilnie i podczas obrad Trybunału Litewskiego asystował duchownym prowadzącym procesy sądowe ${ }^{69}$.

Odtąd kanclerz diecezjalny występuje w aktach Kapituły najczęściej w kontekście prowadzonych spraw sądowych w Trybunale Litewskim i jako urzędowy opiekun archiwum kapitulnego. To jego zadaniem

BLAN, f.43-217, ACV, t. 9 (1625-1632), k. 221-221v.

BLAN, f.43-220, ACV, t. 12 (1644-1652), s. 747.

BLAN, f.43-221, ACV, t. 13 (1652-1663), k. 178 nn.

BLAN, f.43-222, ACV, t. 14 (1633-1666), k. 69. 
była troska o porządkowanie akt, ich rewindykowanie, prowadzenie regestrów i bezpieczne przechowywanie materiału archiwalnego.

Wkrótce duchowni nominowani na urząd kanclerza, chcąc przynajmniej na zewnątrz upodobnić się do członków Kapituły, poczęli zabiegać o przywilej noszenia szat zastrzeżonych dotąd prałatom i kanonikom. Tak więc w roku 1678 kanclerz nominat ksiądz Jan Woronowicz zwrócił się z prośbą o pozwolenie wkładania mantoletu i rokiety w te dni, kiedy Kapituła przywdziewała togi lub kapy. Mocą tego samego aktu prosił Woronowicz o najdalszą stallę w Kapitule. Rad by też zająć w procesji miejsce przed krzyżem kapitulnym. Wszystkie te dezyderaty Kapituła rozpatrzyła pozytywnie ${ }^{70}$. Dystynktorium kapitulne otrzymał kanclerz diecezjalny po długich, rozpoczętych w 1742 roku, zabiegach Kapituły i kolejnych kanclerzy u Stolicy Apostolskiej ${ }^{71}$. Na przywilej krzyża kapitulnego przyszło jednak kanclerzowi czekać pełne 26 lat, aż do dnia 2 marca 1768 roku, kiedy to Kapituła, po uzyskaniu z Rzymu stosownych upoważnień, na sesji generalnej podjęła uchwałę o przyznaniu księdzu Bukatemu, kanclerzowi, tegoż przywileju ${ }^{72}$.

$\mathrm{Na}$ inkorporowanie urzędu kanclerskiego do kolegium kapitulnego Kapituła zdecydowała się dopiero na sesji generalnej 12 października 1742 roku. Prałaci i kanonicy motywowali swą decyzję względami czysto praktycznymi twierdząc, iż kanclerz diecezjalny jako kanonik gremialny cieszyłby się większą powagą przy prowadzeniu spraw sądowych oraz mógłby, już bez przeszkód, korzystać z wiedzy i doświadczenia członków Kapituły. Tak przygotowany projekt przesłano biskupowi. Pozostał on zapewne bez odpowiedzi, jako że nie odnotowano w aktach żadnej wzmianki o reakcji biskupa. Daje to podstawę do przypuszczenia, iż projekt ten jako taki nie wszedł wówczas w życie. Zacytowany jednakże przy tej okazji fragment dokumentu erekcyjnego urzędu kanclerskiego pozwala ustalić, iż każdorazowy kanclerz był już wówczas nadetatowym kanonikiem, mającym wszystkie płynące z tytułu członkostwa w Kapitule obowiązki z dotyczącym rezydencji włącznie ${ }^{73}$. Wymowa późniejszych źródeł osiemnastowiecznych upoważnia do wniosku, że kanonicy-kanclerze, nie mając dostatecznej motywacji w postaci przysługujących kanonikom gremialnym praw, zwłaszcza do pobierania refekcji, a co za tym idzie, nie podlegając sankcjom karnym za nieobecność podczas nabożeństw, obowiązkom

\footnotetext{
$70 \quad$ BLAN, f.43-235, ACV, t. 17 (1673-1681), s. 572.

71 BLAN, f.43-234, ACV, t. 26 (1739-1744), s. 303.

72 BLAN, f.43-237, ACV, t. 29 (1767-1777), s. 96. 
tym jedynie wyjątkowo czynili zadość. Ponadto kanclerz diecezjalny z natury swego urzędu zobowiązany do troski o integralność funduszów kościelnych, siłą rzeczy częściej odwiedzający salę sądową, niż katedrę, nie byłby w stanie, przy najszczerszych nawet chęciach, pełnić obowiązki kanonika gremialnego. Kapituła jakby zdała się tego nie rozumieć, próbując na jesieni 1742 roku gwałtem inkorporować go do swego grona i proponując mu ostatnie miejsce w stallach z prawem wejścia po śmierci kanonika gremialnego na jego miejsca, bez możliwoHistoria ści jednakże awansu do stalli prałackiej. Tego rodzaju perspektywy, jak też proponowane mu dodatkowe, lokowane na altarii słuckiej, uposażenie o niepewnych dochodach w wysokości 15.000 złp., nie stanowiły dla kanclerza z pewnością szczególnej zachęty ku podejmowaniu jakichkolwiek zabiegów w celu urzeczywistnienia tak skonstruowanego planu. Zatem brak zdecydowanego zainteresowania jego realizacją ze strony samego kanclerza mógł być jedną z przyczyn upadku tego projektu. Niedoprecyzowany status kanclerza diecezjalnego w Kapitule Katedralnej Wileńskiej nie uległ zmianie aż do końca Rzeczypospolitej Obojga Narodów. Znać to wyraźnie w decyzji Kapituły z 2 października 1782 roku dotyczącej sprawowania urzędu deputata duchownego do Trybunału Litewskiego. Stwierdzono wówczas, że urząd ten będzie sprawował jeden z prałatów oraz dwóch kanoników kolejno „według starszeństwa” lub na prośbę Kapituły, nie wyłączając kanclerza ${ }^{74}$. Owo sformułowanie „nie wyłączając kanclerza” pozwala przypuszczać, że jeszcze w końcu XVIII stulecia status kanclerza diecezjalnego w Kapitule nie był prawnie określony, a jego pozycja zależała od aktualnych okoliczności i potrzeb. Duchowny pełniący ten urząd nadal zajmował ostatnie, po kanonikach, miejsce w stallach bez możliwości awansu i nie miał prawa do korzystania z dóbr refekcyjnych Kapituły. Na sesjach kapitulnych pozbawiony był prawa czynnego głosu, zatem bywał na nich jedynie sporadycznie.

Reasumując warto zwrócić uwagę na ewolucję pozycji kanclerza diecezjalnego wileńskiego w systemie zarządu diecezją. Postrzegany początkowo jako człowiek z najbliższego otoczenia biskupa diecezjalnego i jemu całkowicie oddany, budził w Kapitule nieufność, zatem w stalli, a zwłaszcza w kapitularzu, niemile był widziany. Próby wprowadzenia go na stałe do kapitulnego gremium, podejmowane przez kolejnych biskupów, zainteresowanie tą sprawą dworu królewskiego i nuncjatury pozwalają na sformułowania tezy, iż problem ten sięgał daleko poza granice diecezji wileńskiej i niewykluczone, że był przejawem prób ograniczenia wpływów kapituł na zarząd diecezją. 


\section{Tytułem rekapitulacji}

Fundacje kolejnych prałatur i kanonii uwarunkowane były aktualnymi potrzebami diecezji i katedry, stąd w swych początkach wszyscy członkowie Kapituły byli jednocześnie urzędnikami wyposażonymi w ściśle określony zakres obowiązków i w środki potrzebne do ich realizacji. Znać to chociażby w określeniach poszczególnych godności: prepozyt, dziekan, archidiakon, kustosz, scholastyk, kantor. W miarę rozbudowy organizacji i ustroju Kapituły oraz na skutek zmian zachodzących w organizacji diecezji i ewolucji prawa kościelnego i państwowego, poszczególne urzędy bądź zanikały, bądź też zmieniało się spectrum spraw doń przynależnych. Skutkowało to w konsekwencji tym, że już w połowie XVIII wieku po dotychczasowych urzędach pozostały tylko nazwy określające poszczególne godności prałackie. Pojawili się natomiast rekrutujący się spośród kanoników lub z grona niższego kleru diecezjalnego urzędnicy, których pracę nierzadko jedynie formalnie nadzorowali prałaci lub duchowni przez nich delegowani. W praktyce ich działalność kontrolowała Kapituła jako korporacja gromadząca się na regularnie zwoływanych sesjach partykularnych oraz na dwóch w ciągu roku sesjach gremialnych.

Kapituła Katedralna Wileńska w okresie przedrozbiorowym, wyposażona w szerokie prerogatywy wynikające z prawa kościelnego, posiadając nadto liczne przywileje monarsze i te, nadane przez Stolicę Apostolską, stanowiła skuteczne ciało kontrolne, niepozwalające ordynariuszom na zbytnią fantazję w zarządzie diecezją, hamując ich co bardziej śmiałe, nierzadko sprzeczne z interesami kapitulnego gremium decyzje. Prałaci pełniący przywiązane do ich godności funkcje oraz odpowiedzialni za realizację postanowień i decyzji Kapituły urzędnicy, w swych poczynaniach byli odpowiedzialni przede wszystkim przed korporacją kapitulną. Jedynie w kwestiach spornych strona pokrzywdzona odwoływała się do biskupa, który przejmował rolę arbitra. Niewielka liczba owych interwencji świadczy, że Kapituła niechętnie odnosiła się w tych sprawach do rządcy diecezji, nierzadko dowodząc w ten sposób, że jest korporacją, potrafiącą skutecznie funkcjonować także w sytuacjach kryzysowych.

Słowa klucze: Wielkie Księstwo Litewskie, Wilno, katedra, kapituła katedralna, prałat, kanonik, kanclerz. 


\section{Bibliografia:}

1. Abraham W., Organizacja Kościoła w Polsce do połowy wieku XII, Lwów 1890.

2. Bartoszewicz J., Kanclerze kapitut, [w:] Encyklopedia Powszechna S. Orgelbranda, t. 13, Warszawa 1863.

3. Dokumenty soborów powszechnych. Tekst taciński i polski, t. 4 (1511-1870): Lateran V, Trydent, Watykan I, oprac. A. Baron, H. Pietras, Kraków 2005.

4. Dola K., Wroctawska kapituta katedralna w XV wieku. Ustrój-sktad osobowy - działalność, Lublin 1983.

5. Fijałek J., Kościót Rzymsko-katolicki na Litwie. Uchrześcijannienie Litwy przez Polskę i zachowanie w niej języka ludu pod koniec Rzeczpospolitej, [w:] Polska i Litwa w dziejowym stosunku, Kraków 1914.

6. Góralski W., Kapituła katedralna w Płocku XII-XVI w. Studium z dziejów organizacji prawnej kapitut polskich, Płock 1979.

7. Kodeks dyplomatyczny katedry i diecezji wileńskiej, J. Fijałek, W. Semkowicz (wyd.), t. 1, z. 1, Kraków 1948.

8. Kumor B., Dzieje diecezji krakowskiej do roku 1794, t. 2, Kraków 1999.

9. Kurczewski J., Kościót zamkowy, cz. 2, Wilno 1910.

10. Nowacki J., Dzieje archidiecezji poznańskiej, t. 2, Archidiecezja poznańska w granicach historycznych i jej ustrój, Poznań 1964.

11. Plöchl W., Geschichte des Kirchenrechts, Bd 1, Wien 1959.

12. Plöchl W., Geschichte des Kirchenrechts, Bd 2, Wien 1962.

13. Polkowski I. (red.), Statuta capitularia Ecclesiae Catherdralis Cracoviensis, Cracoviae 1884.

14. Przybyszewski B., Kapituła krakowska za kanonikatu Jana Dtugosza (1438-1480), [w:] Dtugosiana. Studia historyczne w pięćsetlecie śmierci Jana Dtugosza, Kraków 1980.

15. Relationes status Dioecesium in Magno Ducatu Lithuaniae, P. Rabikauskas (coll.), vol.1. Dioeceses Vilnensis et Samogitiae, Romae 1971.

16. Statuta Capituli Ecclesiae Cathedralis Cracoviensis A. 1328-1478, [w:] H. Heyzman (red.), Staropolskie Prawa Pol. Pom., t. 4, Cracoviae 1875.

17. Vitauskienė B. R., Pasvarstymai apie seniausias katedros vertybes, „Naujasis Židinys - Aidai", 2003, nr 10.

18. Wyczawski H. E., Przygotowanie do studiów w archiwach kościelnych, Kalwaria Zebrzydowska 1990.

19. Zujienè G., Historia skarbca katedry wileńskiej (od zatożenia do dzisiaj, [w:] Skarbiec katedry wileńskiej, Warszawa 2008. 